\title{
Path Analysis on the Biopsychosocial Determinants of Infertility among Reproductive Aged Women in Surakarta, Central Java
}

\author{
Luthfia Zauma'), Uki Retno Budhiastuti'2) \\ Eti Poncorini Pamungkasari3) \\ 1)Masters Program in Public Health, Universitas Sebelas Maret \\ 2)Department of Obstetrics and Gynecology, Dr. Moewardi Hospital, Surakarta \\ 3)Faculty of Medicine, Universitas Sebelas Maret
}

\section{ABSTRACT}

Background: Infertility is a multidimensional problem. This problem occurs not only because of health problems related to anatomic factors such as problems in the fallopian tubes, ovaries, and endometrium, but also there are more factors such as physiological, genetic, and environmental factors. The purpose of this study was to analyze the factors that influence the incidence of infertility in women.

Subjects and Method: A case control study was conducted at the Gynecology Obstetrics Polyclinic and Sekar Fertility Clinic, Dr. Moewardi hospital, Surakarta, Central Java, from October to November 2019. A sample of 200 women reproductive age was selected by fixed disease sampling. The dependent variable was infertility. The independent variables were age, body mass index (BMI), physical activity, endometriosis, family history, exposure to cigarette smoke, and stress. The data were obtained from medical record and questionnaire. The data were analyzed by path analysis run on Stata 13.

Results: Infertility in women was directly increased with age 35 years $(b=1.20 ; 95 \% \mathrm{CI}=$ 0.18 to $2.22 ; \mathrm{p}=0.021$ ), $\mathrm{BMI}<18$ or $\geq 25$ ( $\mathrm{b}=$
2.93; $95 \% \mathrm{CI}=1.95$ to $3.91 ; \mathrm{p}<0.001)$, high physical activity $(b=1.30 ; 95 \% \mathrm{CI}=0.28$ to $2.33 ; \mathrm{p}=$ $0.013)$, endometriosis $(b=1.17 ; 95 \% \mathrm{CI}=0.20$ to 2.13; $\mathrm{p}=0.018)$, exposure to cigarette smoke $(\mathrm{b}=$ $1.19 ; 95 \% \mathrm{CI}=0.20$ to $2.23 ; \mathrm{p}=0.023)$, and severe stress $(b=1.18 ; 95 \% \mathrm{CI}=0.27$ to $2.08 ; \mathrm{p}=0.011)$. Infertility in women was indirectly increased with age, physical activity, and family history of infertile.

Conclusion: Infertility in women is directly increased with age 35 years, BMI $<18$ or $\geq 25$, high physical activity, endometriosis, exposure to cigarette smoke, and severe stress. Infertility in women is indirectly increased with age, physical activity, and family history of infertile.

Keywords: female infertility, risk factors, path analysis

\section{Correspondence:}

Luthfia Zauma. Masters Program in Public Health, Universitas Sebelas Maret, Jl. Ir. Sutami 36A, Surakarta, Central Java, Indonesia, 57126. Email:el.chizauma@gmail.com. Mobile: 0813379 77377 .

Cite this as:

Zauma L, Budhiastuti UR, Pamungkasari EP (2020). Path Analysis on the Biopsysocial Determinants of Infertility among Reproductive Aged Women in Surakarta, Central Java. J Matern Child Health. 5(2): 173-181. https://doi.org/10.26911/thejmch.2020.05.02.07

(†) (-) Journal of Maternal and Child Health is licensed under a Creative Commons

Attribution-Non Commercial-Share Alike 4.o International License.

\section{BACKGROUND}

Infertility is a multidimensional problem with social, economic and cultural implications, which can occur and threatens proportions in countries with strong demographic problems, such as Greece. This prob- lem occurs not only because of health problems related to anatomic factors such as problems in the fallopian tubes, ovaries, and endometrium, but also many other factors such as physiological, genetic, and environmental factors. Farquhar et al. (2019) states 
that the factors that cause infertility in women are ovulation dysfunction, premature ovarian failure (POF) and Primary ovarian insufficiency (POI), the presence of ovarian cysts, abnormalities in the fallopian tubes, pelvis and uterus, and endometriosis. While the risk factors presented by the study are age and lifestyle.

A study by Indarwati (2017) states that the factors that influence the occurrence of infertility in women are age, occupation, stress level, body mass index, and abnormalities of reproductive organs. World Health Organization (WHO) states that infertility is a global health problem faced by about $8-10 \%$ of couples. Globally this means that 50-80 million people experience infertility problems.

The Central Statistics Agency (BPS) in 2011 out of a total 237 million people in Indonesia, there were $+/-39.8$ million women of childbearing age, but $10-15 \%$ of them were declared infertile or infertile and increased to $15-25 \%$ of the total number of existing couples (Riskesdas, 2013). The incidence of infertility from female factors is $65 \%$, male factors are $20 \%$, and $15 \%$ are other factors and conditions that are still unknown (Oktarina, 2014).

Data of Sekar Fertility Clinic medical records of RSUD DR. Moewardi Surakarta in 2008 reported 979 couples, 2,205 couples in 20-12, and continued to increase to 4,055 couples in 2016 (Retiyansa, 2019). The number of new patients at Sekar Fertility Clinic Dr. Moewardi there were 1,083 infertile couples out of a total number of patients of 3,774 infertile couples. This number is lower compared to the previous year. Of these $74 \%$ are female infertility (Setiawan, 2017).

\section{SUBJECTS AND METHOD}

\section{Study Design}

This was an analytic observational study with a case control design. The study was carried out at the Obstetrics and Gynecology Clinic and Sekar Fertility Clinic, dr. Moewardi hospital, Surakarta, Central Java, from October to November 2019.

\section{Population and Sample}

A sample of 200 women reproductive age was selected by fixed disease sampling, consisting of 50 infertile women and 150 fertile women.

\section{Study Variables}

The dependent variable is the incidence of infertility in women. The independent variables are age, body mass index, body activity, endometriosis, family history, exposure to cigarette smoke, and stress.

\section{Operational Definition of Variables}

Infertility was the inability of a woman to conceive/have children or require a period of more than 1 year to conceive/have children without using contraception. The tool used to collect data was medical record. The measurement scale was categorical, coded o for fertile and 1 for infertile.

Age was a unit of time to measure the time of the existence of an object or creature, both living and dead. The age of the study subjects was calculated from the beginning of birth until the time the study was conducted. The data were collected by questionnaire. The measurement scale was continuous and transformed into dichotomous, coded o for $<35$ years and 1 for $\geq 35$ years.

Body mass index was a simple calculation using a person's height and weight to measure a person's body mass. The data were collected by medical record. The measurement scale was continuous and transformed into dichotomous, coded o for BMI 18-25 and 1 for $\mathrm{BMI}<18$ or $\geq 25$.

Physical activity was any movement carried out by the body and produced by skeletal muscle and requires energy. The data were collected by questionnaire. The measurement scale was continuous and transformed into dichotomous, coded o for score $<7.9$ and 1 for 
Zauma et al. / Path Analysis on the Biopsysocial Determinants of Infertility

score $\geq 7.9$.

Endometriosis was a complex disease characterized by inflammation and endometrial bleeding. Pain is caused by endometrial tissue in the pelvic region outside the uterus. The data were collected by medical records. The measurement scale was categorical, coded $o$ for no and 1 for yes.

Family history was the presence or absence of a family member (mother or female sibling) who has an infertile history. The data were collected by questionnaire. The measurement scale was categorical, coded o for no and 1 for yes.

Exposure to cigarette smoke was exposure to all chemicals from burning cigarettes on smokers and non-smokers. The data were collected by questionnaire. The measurement scale was categorical, coded o for not exposed and 1 for exposed.

Stress is a prolonged psychological status that arises to cause negative effects on mood, immune function, and body health. The data were collected by questionnaire. The measurement scale was continuous and trans-

formed into dichotomous, coded o for score $<20$ and 1 for score $\geq 20$.

\section{Data Analysis}

Data in this study were processed using univariate analysis, bivariate analysis, and multivariate analysis using path analysis to determine the direct and indirect effects of independent variables on the risk factors of infertility in women.

\section{Research Ethic}

This study was conducted based on research ethics, namely informed consent, anonymity, confidentiality, and ethical eligibility. Ethics permit in this study was obtained from the Health Research Ethics Commission of dr. Moewardi hospital, Surakarta, Central Java, Indonesia Number 1,066/IX/HREC/2019.

\section{RESULTS}

1. Sample Characteristics

Categorical data descriptions describe continuous data. The results of the analysis of the description of categorical data are shown in Table 1.

Table 1. Frequency distribution of continuous research data variables

\begin{tabular}{lccccc}
\hline Variable & n & Mean & SD & Min. & Max. \\
\hline Age & 200 & 30.1 & 6.3 & 19 & 49 \\
BMI & 200 & 22.5 & 3.2 & 16.5 & 31.1 \\
Stress & 200 & 17.4 & 9.3 & 5 & 38 \\
Physical Activity & 200 & 8.2 & 1.4 & 4.6 & 11.1 \\
\hline
\end{tabular}

\section{Univariate analysis}

Table 2 shows that the number of study subjects the majority of fertile women aged $<35$ years is amounting 146 people (73\%). The subjects in this study were the majority had a normal body mass index with 143 people (71.5\%) and subjects with an abnormal BMI were 47 people (28.5\%). Most of the subjects were not exposed to cigarette smoke amounting to 154 people (77\%) and subjects who were exposed to cigarette smoke as many as 46 people (23\%). The majority of the subjects did not have a family history of infertility as many as 150 people (75\%) and subjects who had a family history of infertility were as many as 50 people (50\%). Subjects who did not have more endometriosis were 148 people (74\%) compared to subjects who had a history of endometriosis as many as 52 people (26\%). The majority of subjects did high activity as many as 130 people (65\%) when compared with subjects who carried out normal activities as many as 70 people (35\%). Subjects with normal stress levels more with a total of 130 people (65\%) com- 
Zauma et al. / Path Analysis on the Biopsysocial Determinants of Infertility

pared with subjects with high stress, as many as 70 people (35\%).

Table 2. Frequency distribution of categorical data research variables

\begin{tabular}{llcc}
\hline \multicolumn{1}{c}{ Characteristics } & Frequency & Percent (\%) \\
\hline Infertility & No & 150 & 75.00 \\
Age & Yes & 50 & 25.00 \\
& $<35$ years & 146 & 73.00 \\
BMI & $\geq 35$ years & 54 & 27.00 \\
& $18-25$ & 143 & 71.50 \\
Smoke & $<18$ or $\geq 25$ & 57 & 28.50 \\
& No & 154 & 77.00 \\
Family History & Yes & 46 & 23.00 \\
\multirow{3}{*}{ Endometriosis } & No & 150 & 75.00 \\
& No & 50 & 25.00 \\
Physical Activity & Yes & 148 & 74.00 \\
& Score $<7.9$ & 52 & 26.00 \\
Stress & Score $\geq 7.9$ & 70 & 35.00 \\
& Normal & 130 & 65.00 \\
& High & 130 & 65.00 \\
\end{tabular}

Table 3. Results of bivariate analysis of risk factors for infertility in women

\begin{tabular}{|c|c|c|c|c|c|c|c|c|}
\hline \multirow{3}{*}{ Variable } & \multicolumn{4}{|c|}{ Frequency } & \multirow{2}{*}{\multicolumn{2}{|c|}{ Total }} & \multirow{3}{*}{ OR } & \multirow{3}{*}{$\mathbf{P}$} \\
\hline & \multicolumn{2}{|c|}{ Fertile } & \multicolumn{2}{|c|}{ Infertile } & & & & \\
\hline & $\mathbf{n}$ & $\%$ & $\mathbf{N}$ & $\%$ & $\mathbf{n}$ & $\%$ & & \\
\hline \multicolumn{9}{|l|}{ Age } \\
\hline$<35$ & 123 & 84.2 & 23 & 15.8 & 146 & 100 & \multirow{3}{*}{$5 \cdot 34$} & \multirow{3}{*}{$<0.001$} \\
\hline$>35$ & 27 & 50.0 & 27 & 50.0 & 54 & 100 & & \\
\hline \multicolumn{7}{|l|}{ BMI } & & \\
\hline Normal (18-25) & 129 & 90.2 & 14 & 9.8 & 143 & 100 & \multirow{3}{*}{$15 \cdot 79$} & \multirow{2}{*}{$<0.001$} \\
\hline Not Normal $(<18$ or $>25)$ & 21 & 36.8 & 36 & 63.2 & 57 & 100 & & \\
\hline \multicolumn{8}{|l|}{ Smoke } & \\
\hline No & 129 & 83.8 & 25 & 16.2 & 154 & 100 & \multirow{2}{*}{6.14} & \multirow{2}{*}{$<0.001$} \\
\hline Yes & 21 & 45.7 & 25 & 54.3 & 46 & 100 & & \\
\hline \multicolumn{9}{|l|}{ Family History } \\
\hline No & 124 & 82.7 & 26 & $17 \cdot 3$ & 150 & 100 & \multirow{3}{*}{4.40} & \multirow{2}{*}{$<0.001$} \\
\hline Yes & 26 & 52.0 & 24 & 48.0 & 50 & 100 & & \\
\hline \multicolumn{8}{|l|}{ Endometriosis } & \\
\hline No & 119 & 80.4 & 29 & 19.6 & 148 & 100 & \multirow{2}{*}{2.78} & \multirow{2}{*}{0.003} \\
\hline Yes & 31 & 59.6 & 21 & 40.4 & 52 & 100 & & \\
\hline \multicolumn{9}{|l|}{ Physical Activity } \\
\hline Score $<7.9$ & 53 & $75 \cdot 7$ & 17 & $24 \cdot 3$ & 70 & 100 & \multirow{2}{*}{1.06} & \multirow{2}{*}{0.86} \\
\hline Score $\geq 7.9$ & 97 & 74.6 & 33 & 25.4 & 130 & 100 & & \\
\hline \multicolumn{9}{|l|}{ Stress } \\
\hline Normal & 107 & 82.3 & 23 & 17.7 & 130 & 100 & \multirow{2}{*}{2.92} & \multirow{2}{*}{0.001} \\
\hline High & 43 & 61.4 & 27 & 38.6 & 70 & 100 & & \\
\hline
\end{tabular}

\section{The result of bivariate analysis}

Table 3 shows age $(\mathrm{OR}=5.34 ; \mathrm{p}=<0.001)$, BMI (OR= 15.79; $\mathrm{p}<0.001)$, physical activity $(\mathrm{OR}=1.06 ; \mathrm{p}=0.864)$, endometriosis $(\mathrm{OR}=$ $2.78 ; \mathrm{p}=0.003)$, family history $(\mathrm{OR}=4.40$; $\mathrm{p}=<0.001)$, exposure to cigarette smoke $(\mathrm{OR}=6.14 ; \mathrm{p}=<0.001)$, and stress $(\mathrm{OR}=$ 2.92; $\mathrm{p}=0.001)$.

4. The result of path analysis

a. Model Specification 
This explains the relationship between the variables studied. There are 8 variables calculated in this study, namely infertility, age, body mass index, body activity, endometriosis, family history, exposure to cigarette smoke, and stress.

\section{b. Model Identification}

The variables measured include:

1) Number of measured variables: 8

2) Number of endogenous variables: 3

3) Number of exogenous variables: 5
4) Number of parameters: 8

The degree of freedom ( $\mathrm{df}$ ) formula is: $\mathrm{df}=$ (number of measured variables $\mathrm{x}$ (number of measured variables +1) / 2) - (endogenous variables + exogenous variables + number of parameters)

$=(8 \times(8+1) / 2)-(3+5+8)=20$

Path analysis can be done if $\mathrm{df} \geq 0$, while in the identification of the model in this path analysis the value of $\mathrm{df}$ is 20 which means over identified or path analysis can be used.

Table 4. Results of path analysis on the factors influencing infertility in women

\begin{tabular}{|c|c|c|c|c|c|}
\hline \multirow[b]{2}{*}{ Dependent Variable } & \multirow[b]{2}{*}{ Independent Variable } & \multirow[b]{2}{*}{$\mathbf{b}$} & \multicolumn{2}{|c|}{$(95 \%) \mathrm{CI}$} & \multirow[b]{2}{*}{$\mathbf{p}$} \\
\hline & & & $\begin{array}{c}\text { Lower } \\
\text { Limit }\end{array}$ & $\begin{array}{l}\text { Upper } \\
\text { Limit }\end{array}$ & \\
\hline \multicolumn{6}{|l|}{ Direct Effects } \\
\hline \multirow[t]{6}{*}{ Infertility in women } & $\leftarrow$ Age & 1.20 & 0.18 & 2.22 & 0.021 \\
\hline & $\leftarrow$ BMI & 2.93 & 1.95 & 3.91 & $<0.001$ \\
\hline & $\leftarrow$ Smoke & 1.19 & 0.16 & 2.23 & 0.024 \\
\hline & $\leftarrow$ Endometriosis & 1.17 & 0.20 & 2.14 & 0.018 \\
\hline & $\leftarrow$ Physical Activity & 1.30 & 0.28 & 2.33 & 0.013 \\
\hline & $\leftarrow$ Stress & 1.17 & 0.72 & 2.08 & 0.011 \\
\hline \multicolumn{6}{|l|}{ Indirect Effect } \\
\hline BMI & $\leftarrow$ Physical Activity & -0.84 & -1.47 & -0.21 & 0.009 \\
\hline Endometriosis & $\leftarrow$ Family History & 0.71 & 0.01 & 1.41 & 0.048 \\
\hline & $\leftarrow$ Age & 0.67 & -0.02 & 1.36 & 0.056 \\
\hline Stress & $\leftarrow$ Family History & 0.74 & 0.08 & 1.39 & 0.028 \\
\hline $\begin{array}{l}\text { Physical Activity } \\
\text { N observation }=200 \\
\text { Log likelihood }=-543.96\end{array}$ & $\leftarrow$ Age & -0.98 & -1.62 & -0.34 & 0.003 \\
\hline
\end{tabular}

Several variables have an indirect influence on the incidence of infertility in women, namely physical activity on BMI $(b=-0.84$; $95 \% \mathrm{CI}=-1.47$ to $-0.21 ; \mathrm{p}=0.009$ ), family history of infertility with endometriosis $(b=$ $0.70 ; 95 \% \mathrm{CI}=0.01$ to $1.41 ; \mathrm{p}=0.048$ ), age with endometriosis $(b=0.67 ; 95 \% \mathrm{CI}=-0.02$ to $1.36 ; \mathrm{p}=0.056$ ), family history of infertility with stress $(b=0.73 ; 95 \% \mathrm{CI}=0.81$ to $1.40 ; \mathrm{p}=0.028$ ), age with physical activity $(b=-0.98 ; 95 \% \mathrm{CI}=-1.62$ to $-0.34 ; \mathrm{p}=0.003$ ).
Table 4 shows that there is a direct relationship between the age variable and the incidence of infertility age $(\mathrm{b}=1.20 ; 95 \% \mathrm{CI}=$ 0.18 to $2.22 ; \mathrm{p}=0.021), \mathrm{BMI}(\mathrm{b}=2.93 ; 95 \%$ $\mathrm{CI}=1.95$ to $3.91 ; \mathrm{p}<0.001)$, physical activity $(b=1.20 ; 95 \% \mathrm{CI}=0.28$ to $2.33 ; \mathrm{p}=0.013)$ endometriosis $(b=1.17$; 95\% CI= 0.20 to 2.13; $\mathrm{p}=0.018)$, cigarette smoke exposure $(\mathrm{b}=1.19$; 95\% $\mathrm{CI}=0.16$ to $2.23 ; \mathrm{p}=0.024$ ), and stress $(b=1.18 ; 95 \% \mathrm{CI}=0.27$ to $2.08 ; \mathrm{p}=0.011)$. 


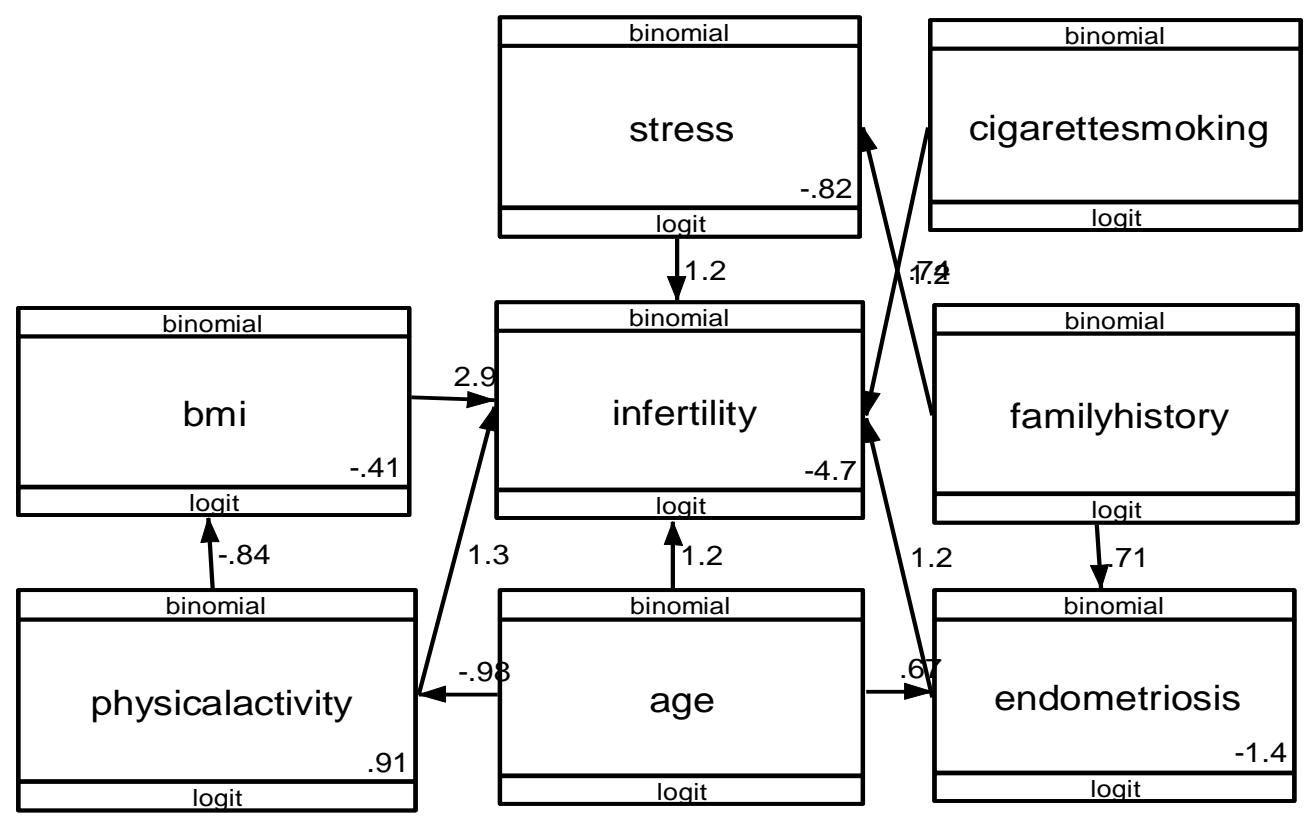

Figure 1. Path Analysis Model with Estimated Values

\section{DISCUSSION}

\section{The Effect of Body Mass Index on In- fertility in Women}

Based on the results of the analysis, body mass index has a significant effect on infertility in women directly. Women with an abnormal BMI ( $<18$ or $>25$ ) have a higher risk of experiencing infertility.

This study was in line Cai et al. (2017), which states that BMI is a factor that influence the occurrence of infertility and risky pregnancy. A low BMI can also indicate inadequate intake and energy status, thereby affecting the concentration of gonadotropins, follicular growth and oocyte quality.

Women with more weight experience irregular menstrual cycles twice as common as women with normal body weight. Overweight women are more prone to become infertile compared to women with normal $\mathrm{BMI}$, this is because overweight women have resistance to insulin, hyperinsulinemia, hyperandrogenemia, and increased aromatization of androgens against estrogen in peri- pheral tissues.

In addition, obesity causes changes in gonadotropin release ( $\mathrm{GnRH})$, which is a decrease in sex hormone-binding glonulin (SHBG). Growth hormones and growth factor proteins such as insulin, increased levels of leptin and decreased levels of adinopectin (Sanlier and Yorusun, 2018).

The higher the activity carried out, the reduced body mass index. The results of this study are in accordance with a study by Bradbury (2017), which states that high physical activity is related to the average percentage of a person's body fat. The results also showed a relationship between a woman's age and physical activity.

\section{The Effect of Age on Infertility in Women}

Based on the results of the analysis, age directly affects infertility in women and is statistically significant. Women whose age $\geq 35$ years have a greater risk for infertility.

The results of this study are in line with a study by Purwoastuti and Walyani (2015), 
female fertility naturally decreases from the age of 35 years due to fewer egg reserves. As women get older, their hormonal become imbalances and it decreased the function of the reproductive organs.

Hormonal imbalances in a woman's body can cause disruption in the menstrual cycle. Increasing age of women makes the hormones in the body become unbalanced. This results in the FSH hormone increasing, the follicular phase getting shorter, while the LH level and duration of the luteal phase do not change, resulting in irregular periods. Increasing age of women makes the number of ovarian follicles decreases.

The decrease in the number of follicles becomes faster when a woman is more than 38 years old. Follicles also become less sensitive to gonadotropin stimulation resulting in decreased female fertility (Indarwati, 2017)

\section{The Effects of Physical Activity on Infertility in Women}

The results of this study are consistent with a study by Gudmundsdottir et al. (2011), which states there is a relationship between physical activity and menstrual disorders in women. Women with high physical activity experience an increase in cycle length in women $\geq$ 25 years with a higher frequency of LTPA and shortening of the cycle, increased bleeding time and menstrual cycle irregularities, this will affect the fertility of women.

The results also showed a relationship between a woman's age and physical activity. The higher the activity of a woman, the less physical activity is carried out. This is because a person's stamina decreases as he gets older so physical activity is reduced.

\section{The Effects of Endometriosis on Infertility in Women}

Based on the results of research analyzes, endometriosis significantly influences the incidence of infertility in women. Women who have endometriosis have a higher risk of experiencing infertility.
The results of this study are in line with Prescott et al. (2016) which states that the risk of infertility has doubled in women $<35$ years with endometriosis. Endometriosis can interfere with fertility through various pathways, including peritoneal inflammation and endocrine disorders, which then disrupt ovarian function and ultimately reduce the number of oocytes (Tanbo et al., 2017).

The results of the analysis show that family history through endometriosis has an indirect effect on infertility in women. Study by Peterson et al. (2014) states that a family history of infertility increases the likelihood of a diagnosis of endometriosis. Women who have a family history of endometriosis are more likely to have endometriosis.

\section{The Effects of Cigarette Smoke Ex- posure on Infertility in Women}

Based on the results of the analysis, exposure to cigarette smoke has a significant effect on the incidence of infertility in women. Women who are often exposed to secondhand smoke have a higher risk of experiencing infertility.

The results of this study are in line with the study by Oboni et al. (2016), which states that women who smoke or are exposed to cigarette smoke are more at risk for infertility or a small number of children compared to women who do not smoke.

Tens of up to thousands of compounds found in cigarette smoke (from active smokers) and side stream smoke (from passive smokers or SHS) are very influential on women's reproductive health. Tobacco poison affects fertility by influencing folliculogenesis, oogenesis, steroid genesis, embryonic transport and implantation, endometrial angiogenesis, uterine blood flow and myometrial growth. Minimum smoke exposure time so that someone can be categorized as passive smokers is 15-6o minutes/day (Dechanet, 2011; Titisari, 2011).

\section{The Effects of Stress on Infertility in Women}


Based on the results of analyzes, stress has a significant effect on the incidence of infertility in women. Women who have high stress levels have a risk of experiencing infertility.

The results of this study are in line with the study by Hajela et al. (2016), which states that women with a history of depression are twice as likely to experience infertility. The level of stress can have an impact on the number of follicles. When the body responds to stress, the body will produce glucocorticoid hormone, cortisol from the adrenal glands. Cortisol that results from stress can cause follicular numbers to decrease (Setiyono et al., 2015).

Cortisol can also interfere with the pulsation of the GnRH hormone so that it makes the level of the FSH hormone decrease and results in a decreased number of follicles. The analysis shows that family history of stress influences infertility in women indirectly. Study subjects who have a family history of infertile are more at risk of experiencing higher stress than women who have no family history of infertile. Infertility in women is directly increased with age 35 years, $\mathrm{BMI}<18$ or $\geq 25$, high physical activity, endometriosis, exposure to cigarette smoke, and severe stress. Infertility in women is indirectly increased with age, physical activity, and family history of infertile.

\section{AUTHOR CONTRIBUTION}

Luthfia Zauma is the main researcher who played a role in conducting study, collecting data, formulating articles, and processing data. Uki Retno Budihastuti played a role in the formulation of the mindset in study. Eti Poncorini Pamungkasari played a role in the formulation of the methods and discussion of results.

CONFLICT OF INTEREST

There is no conflict of interest in this study.
This study is self-funded.

ACKNOWLEDGEMENT

Our gratitude goes to Dr. Moewardi hospital, Surakarta who has allowed this study to be carried out. Thank you also to all subjects who are willing and cooperative of this study.

\section{REFERENCE}

Cai J, Liu L, Zhang J, Qiu H, Jiang X, Li P, Sha A, Ren J(2017). Low body mass index compromises live birth rate in fresh transfer in vitro fertilization cycles: a retrospective study in a Chinese population. Fertil Steril, 107: 422-429. https://doi.org/10.1016/j.fertnstert.2016.10.029.

Dechanet C, Anahory T, Mathieu-Daude JC, Reyftmann L, Hamamah S, Hedon B, Deechaud H (2011). Effects of cigarette smoking onreproduction. Hum Reprod Update 17: 76-95. https://doi.org/10.1093/humupd/dmq033.

Farquhar C, Bhattacharya S, Repping S, Mastenbroek S, Kamath M, Marjoribanks J, Boivin J (2019). Female subfertility. Lancet, 5(7): 1-21. https://doi.org/10.1016/So140-6736(02)09417-5. Gudmundsdottir SL, Flanders WD, Augestad LB (2011). A longitudinal study of physical activity and menstrualcycle characteristics in healthy Noerwegian women-The nortronderlag health study. Norsk Epidemiol. 20(2): 163-171. https://doi.org/10.5324/nje.v2oi2.1337

Hajela S, Prasad S, Kumaran A, Kumar Y (2016). Stres and infertility: a review. Int J Reprod Contracept Obstet Gynecol, 940-943. https://doi.org/10.18203/23201770.ijrcog20160846.

Indarwati I, Budihastuti UR, Dewi YLR (2017). Analysis of factors influencing female infertility. Journal of Maternal and Child Health, 02(02): 150-161. https://doi.org/10.26911/thejmch.20- 
Zauma et al. / Path Analysis on the Biopsysocial Determinants of Infertility

17.02.02.06.

Oboni JB, Vidal PM, Bastardot F, Vollenweider P, Waeber G (2016). Impact of Smoking on Fertility and Age of Menopause: A Population-Based Assessment. BMJ Open 6(11): 1-9. http://dx.doi.org/10.1136/bmjopen-2016-012015.

Oktarina A, Abadi A, Bachsin R (2014). Faktor-faktor yang memengaruhi infertilitas pada wanita di klinik fertilitas endokrinologi reproduksi (Factors affecting infertility in women in reproductive endocrinology fertility clinics). 46(4): 295-300. Retrieved from ejournal.unsri.ac.id/index.php/mks/article/download/2722/pdf.

Prescott J, Farland LV, Tobias DK, Gaskins AJ, Spiegelman D, Chavarro JE, RichEdwards JW, Barbieri RL, Missmer SA (2016). A prospective cohort study of endometriosis and subsequent risk of infertility. Hum Reprod, 31: 1475-82. https://doi.org/10.1093/humrep/dewo85.

Retiyansa Y, Indarto D, Murti B (2019). Path analysis on the associations between infertility, stres, and depression among women in surakarta, Central Java. J Matern Child Health, 4(4): 260-266. https://doi.org/10.26911/thejmch.201-
9.04.04.05.

Sanlier N, Yorusun TO (2018). The relationship between infertility and nutrition. $J$ Nutr Health Sci, 5(2): 207. https://doi.org/10.15744/2393-9060. 5.207

Rizki S (2017). Gambaran idenditas diri pada pasangan infertile di RSUD Dr. Moewardi (The description of self-identity in infertile couples in Dr. Moewardi). Universitas Muhammadiyah Surakarta. http://v2.eprints.ums.ac.id/archive/etd/60273

Setiyono, Awik, Prasetyo B, Maramis M (2015). Pengaruh tingkat stres dan kadar kortisol dengan jumlah folikel dominan pada penderita infertilitas yang menjalani fertilisasi invitro (Effect of stress levels and cortisol levels with the number of dominant follicles in infertility patients undergoing vitro fertilization). Majalah Obstetri \& Ginekologi 23(3): 128-132. http://dx.doi.org/10.20473/mog.V23I32015.128-132.

Tanbo, Tom, Fedorcsak P (2017). Endometriosis-associated infertility: aspects of pathophysiological mechanisms and treatment options. Acta Obstet Gynecol Scand 96 (6): 659-667. https://doi.org/10.1111/aogs.13082. 